\title{
Pathology Isolation and Identification of Canine Herpesvirus (CHV-1) in Mexico
}

\author{
E. Guillermo Valdivia Lara1, Blanca Lilia Barrón Romero², Laura Cobos Marín³, \\ Jessica Ileana Ángeles Solis ${ }^{1}$, Sofía González Gallardo ${ }^{1}$, Cesar Cuenca Verde ${ }^{1}$, \\ Juan Antonio Montaraz Crespo ${ }^{4}$, Guillermo Valdivia Anda ${ }^{*}$
${ }^{1}$ Facultad de Estudios superiores Cuautitlán, Universidad Nacional Autónoma de México, Estado de México, México
${ }^{2}$ Escuela Nacional de Ciencias Biológicas, Instituto Politécnico Nacional, Ciudad de México, México
${ }^{3}$ Universidad Nacional Autónoma de México, Ciudad Universitaria, Ciudad de México, México
${ }^{4}$ Facultad de Estudios superiores Cuautitlán, Universidad Nacional Autónoma de México, Estado de México, México
Email: guillermo897@hotmail.com, bbarron@ipn.mx, laura.cobosmarin@gmail.com, jessypezy@hotmail.com, sofi-238@hotmail.com, ccuencaverde@hotmail.com, jamc1591@gmail.com, "valdivag@unam.mx

Received 8 April 2016; accepted 26 June 2016; published 29 June 2016

Copyright (C) 2016 by authors and Scientific Research Publishing Inc.

This work is licensed under the Creative Commons Attribution International License (CC BY).

http://creativecommons.org/licenses/by/4.0/

(c) (i) Open Access

\section{Abstract}

This work presents the pathology description, isolation and identification of canine herpesvirus (CHV-1) in Mexico, a virus that causes a generalized hemorrhagic infection in puppies from the canidae family. Methods: Isolates were obtained from puppies that died within the first four weeks of life and had lesions consistent with canine herpesvirus. Results: The main gross lesions were petechial and ecchymotic hemorrhages in kidneys, liver and lungs; proliferative interstitial nephritis; multifocal necrosis in liver and kidneys; and encephalitis with intranuclear inclusion bodies. Herpesvirus was confirmed through direct immunofluorescence, electron microscopy and polymerase chain reaction for DNA polymerase and glycoprotein B genes. Discussion: Eight strains were isolated and identified as canine herpesvirus corresponding to three of the working cases with gross and microscopic lesions very similar to those described in the literature; then, isolates were confirmed by PCR gene amplification, positive reactions on immunofluorescence and observations from electron microscopy. This work represents the first report of this disease, including gross and histological lesions, and confirmation by isolation and identification of the canine herpesvirus in Mexico.

\section{Keywords}

Pathology of Puppies, Canine Herpesvirus, PCR, Electron Microscopy

\footnotetext{
"Corresponding author.
}

How to cite this paper: Valdivia Lara, E.G., Barrón Romero, B.L., Cobos Marín, L., Ángeles Solis, J.I., González Gallardo, S., Cuenca Verde, C., Montaraz Crespo, J.A. and Valdivia Anda, G. (2016) Pathology Isolation and Identification of Canine Herpesvirus (CHV-1) in Mexico. Open Journal of Pathology, 6, 111-121. http://dx.doi.org/10.4236/ojpathology.2016.63014 


\section{Introduction}

The canine herpesvirus (CHV) has been isolated in various countries around the world, and recent studies indicate that it is a prevalent disease in the European canine population [1]-[4]. However, in Mexico, there are no data for this disease; furthermore, it has not been recognized as a disease in Mexico and the World Organisation for Animal Health (OIE) has not included it on any of their current lists.

Evidence of CHV infections has been found mainly through molecular techniques, such as PCR; however, only a few publications have performed viral isolation and identification [5]-[9].

Therefore, our aim was to detect, isolate and identify CHV in Mexico City in a fashion consistent with the current literature and evaluate pathological changes in dogs less than 25 days old that were submitted for necropsy. We accomplished the isolation of MDCK cells and identified CHV using immunofluorescence, polymerase chain reaction and electron microscopy.

\section{Material and Methods}

This study used puppies that died before reaching four weeks of age that were submitted for necropsy. Gross lesions were evaluated and samples were taken from affected organs for histology, immunofluorescence, PCR and viral isolation. Puppies who died during the first four weeks were those with lesions and clinical data consistent with the literature reviewed. We have virus isolated of puppies from 4 to 6 weeks, but the lesions are combined with secondary agents, mainly respiratory bacteria.

Histological evaluations used paraffin embedding and hematoxylin and eosin stain (HE). For immunofluorescence, a commercial conjugated anti CHV-1 (VMRD ${ }^{\mathrm{TM}}$, Inc., WA, USA) was used and the recommended procedure was followed.

For PCR, a commercial DNA extraction kit was used (DNeasy Blood and Tissue Kit, Qiagen ${ }^{\mathrm{TM}}$ ) according to the manufacturer's protocol. Amplification was achieved using the protocol described by Van Devanter et al. 1996 [10] for the DNA polymerase gene. The protocol was based on nested PCR, and for the first reaction, we used two forward and one reverse primer (5'-DFA TTYGAYAGYGCIYTITAYCC-3' (forward), 5'-ILK TCC TGGAGCAGCACAARIYSGCIMTIAA-3' (forward) KG1-5'-GTCTTGCTCACCAGITCIACICCYTT3' (reverse)). For the second reaction, we used one forward (TGV-5'-TGT GTGTCGAACTAYTTYACIGGIGGIGT3') and one reverse primer (IYG-5'CAC CGTAGAGTCICCRTARTCIAT-3'), they were prepared exactly as he described in the citation.

Briefly, for the first reaction, we used $400 \mathrm{ng}$ of DNA, $400 \mathrm{~nm}$ of each primer, $100 \mu \mathrm{M}$ of each dNTP, 10 mMKCl, $10 \mathrm{mM}\left(\mathrm{NH}_{4}\right)_{2} \mathrm{SO}_{4}, 20 \mathrm{mM}$ Tris-HCl, $2 \mathrm{mM} \mathrm{MgSO}_{4}, 0.1 \%$ Triton X-100 at pH 8.8 and 1 unit of Taq polymerase (Bioline ${ }^{\mathrm{TM}}$, USA). The mixture was placed in a Multigene thermocycler (International Labnet ${ }^{\mathrm{TM}}$ ) with an initial incubation at $94^{\circ} \mathrm{C}$ for $5 \mathrm{~min}, 35$ cycles at $94^{\circ} \mathrm{C}$ for $20 \mathrm{sec}, 46^{\circ} \mathrm{C}$ for $30 \mathrm{sec}$, and $72^{\circ} \mathrm{C} 30 \mathrm{sec}$, with a final step of 10 minutes at $72^{\circ} \mathrm{C}$. For the second nested PCR reaction, the same concentrations were used, with $5 \mu \mathrm{l}$ from the first reaction as template DNA. Finally, horizontal electrophoresis was performed with an agarose $3 \%$ gel, contain $0.5 \mu \mathrm{g} / \mathrm{ml}$ ethidium bromide and was visualized on a UV light transilluminator

Different cell lines were used for viral isolation; however, the effect was only observed in the canine kidney line (MDCK, in vitro $\left.{ }^{\mathrm{TM}}, \mathrm{p} 26\right)$, and the rest of the study was performed on MDCK. The tissues were cut into fragments of $0.5 \mathrm{~cm}^{3}$, macerated, passed through a glass PotterTM homogenizer, was manipulated manually for 5 min in an ice bath, suspended 1:10 in PBS and centrifuged twice at $1200 \mathrm{~g}$ for $15 \mathrm{~min}$ at $6^{\circ} \mathrm{C}$. The supernatant was filtered through $0.22-\mu$ Millipore ${ }^{\mathrm{TM}}$ membranes. Then, $0.5 \mathrm{ml}$ were inoculated in a 24 -well microplate, Nunc $^{\mathrm{TM}}$ containing a monolayer of MDCK cells at $70 \%$ confluence. The plates were incubated for 1 hour at $34^{\circ} \mathrm{C}-35^{\circ} \mathrm{C}$. Next, $1.5 \mathrm{ml}$ of minimal essential medium (MEM, in vitro ${ }^{\mathrm{TM}}$ ) was added, with $2 \%$ newborn calf serum $\left(\mathrm{Gibco}^{\mathrm{TM}}\right)$ and allowed to incubate at $34^{\circ} \mathrm{C}-35^{\circ} \mathrm{C}$ for 5 days with daily observations of cell effects. Immunofluorescence was performed on cell cultures that exhibited a cytopathic effect. For this technique, cells were grown to $70 \%$ confluence on treated coverslips (cell culture coverslip, sterile, Thermanox Plastic 13-mm diameter, NUNC ${ }^{\mathrm{TM}}$ ). Cells were infected with viral isolates that were previously made and incubated for $48-72$ hours at $34^{\circ} \mathrm{C}-35^{\circ} \mathrm{C}$. Staining was performed by adding $75 \mu \mathrm{l}$ of conjugate (anti-CHV1 polyclonal antiserum conjugated fluorescein isothiocyanate $\mathrm{VMRD}^{\mathrm{TM}}$ ) for $30 \mathrm{~min}$ at $37^{\circ} \mathrm{C}$ in a moist chamber and visualized by $\mathrm{UV}$ microscopy using an Olympus UVTM.

Two PCR protocols were used on the viral isolate, one directly amplified a fragment of the DNApol gene with an expected molecular size of 215 to 315 bp [10]. The other protocol directly amplified a 120-bp fragment from 
the glycoprotein B gene. The last protocol used one forward (P1: 5 'CAG GACTATTGGACTATAGT3') and one reverse (5 'TTG CAATGCCCCTCATAATT3') primer [11].

Transmission electron microscopy (TEM) was conducted at the electron microscopy laboratory in the Faculty of Superior Studies of Cuautitlan, UNAM. Negative stain was used to stain the Karnofsky fixed sample. Then, a drop of $1 \%$ phosphotungstic acid at $\mathrm{pH} 7.2$ was added for one minute. Grids were withdrawn from the excess reagent and dried at room temperature. The samples were observed and photographed with a transmission electron microscope (JEOL JEM100S $\left.{ }^{\mathrm{TM}}\right)$, and reference pictures of a standard particle size of $60 \mathrm{~nm}\left(\right.$ Sigma $\left.{ }^{\circledR}\right)$ were taken.

\section{Results}

Necropsies were performed on three different puppies. Similar lesions were observed, including corneal opacity, serohemorrhagic fluid in the abdominal cavity, liver enlargement, petechial and echymotic areas, on the liver, lungs and kidneys (Figures 1-3).

The histopathology (Figures 4-6) showed moderate multifocal hemorrhages, moderate to severe diffuse proliferative interstitial pneumonia, moderate multifocal suppurative bronchitis and moderate multifocal lung edema. In the kidneys, we found moderate diffuse congestion, severe diffuse albuminous degeneration, mild multifocal vacuolar degeneration, moderate multifocal hemorrhages with moderate lymphocytic infiltration and moderate interstitial proliferative nephritis, and multifocal necrosis.

The liver showed moderate diffuse congestion, severe diffuse albuminous degeneration, mild to moderate proliferative perivascular hepatitis, mild multifocal hemorrhage, and moderate multifocal necrosis. In the brain, we observed severe congestion, severe diffuse non-suppurative meningoencephalitis, perivascular lymphocytic infiltration, and the presence of intranuclear inclusion bodies in neurons. All of the results agreed with previously reported findings for this disease [12]-[14].

An additional culture sample was donated by Dr. Laura Cobos of UNAM, Mexico.

Cytopathic effects on MDCK cells, ranging from mild to severe, are shown in Table 1. It was possible to identify cytopathic effects on infected cells in all of the organs (Figure 7). This indicated viral shedding in virtually all of the tissues from the puppies and corresponded with the histopathological lesions previously observed.

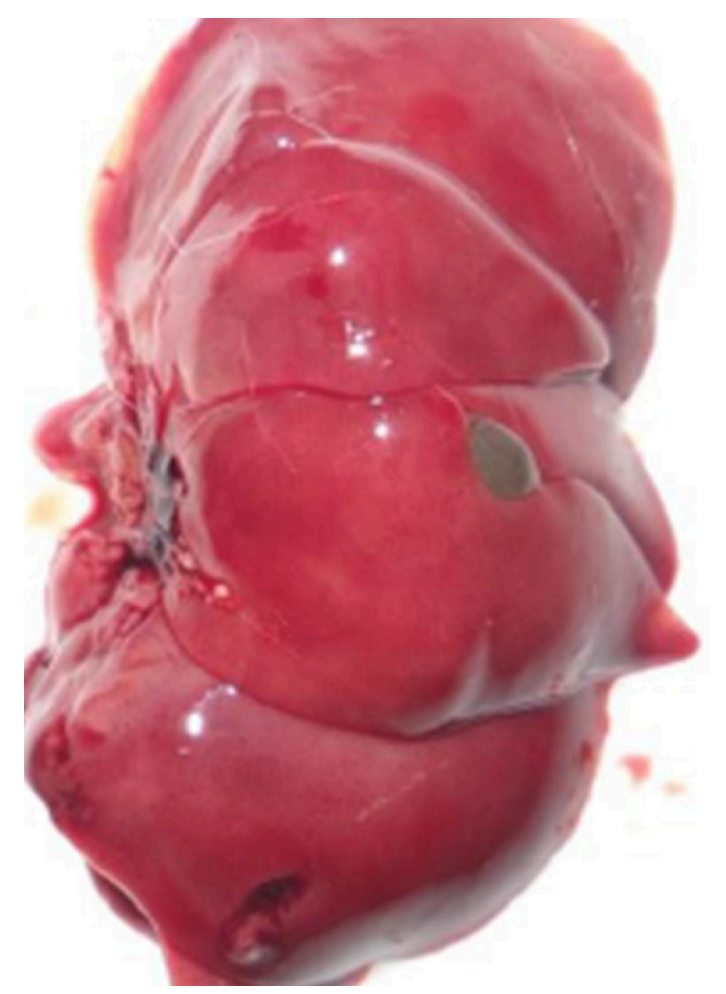

Figure 1. Liver CHV1 FESC2. Liver enlargement, petechial and echymotic areas. 

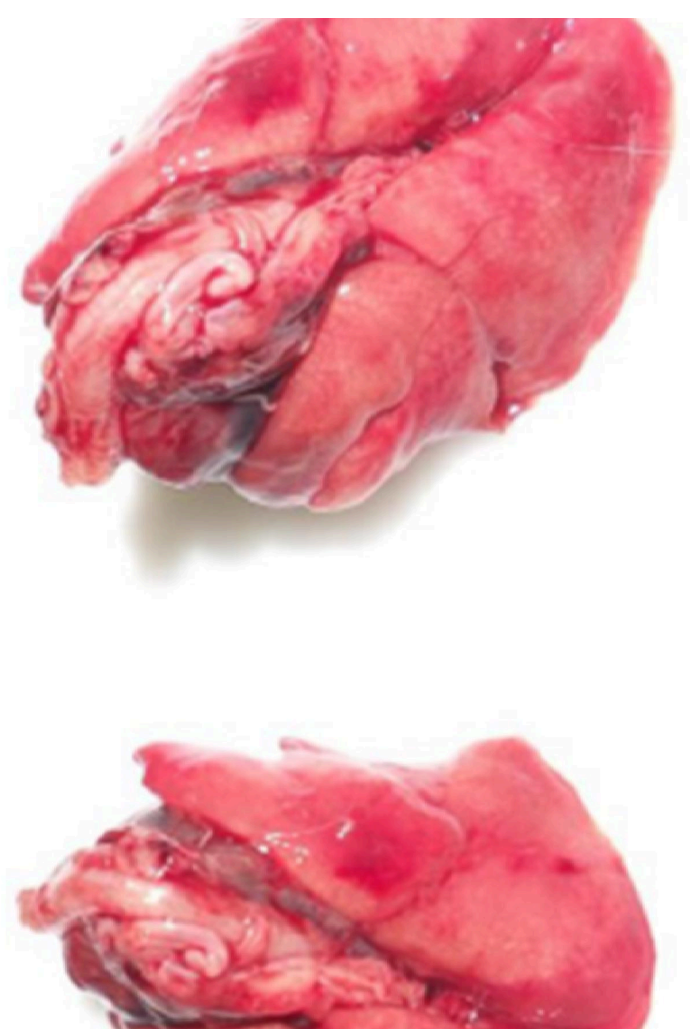

Figure 2. Lungs CHV1 FESC 2. Petechial and echymotic areas, serohemorrhagic fluid.
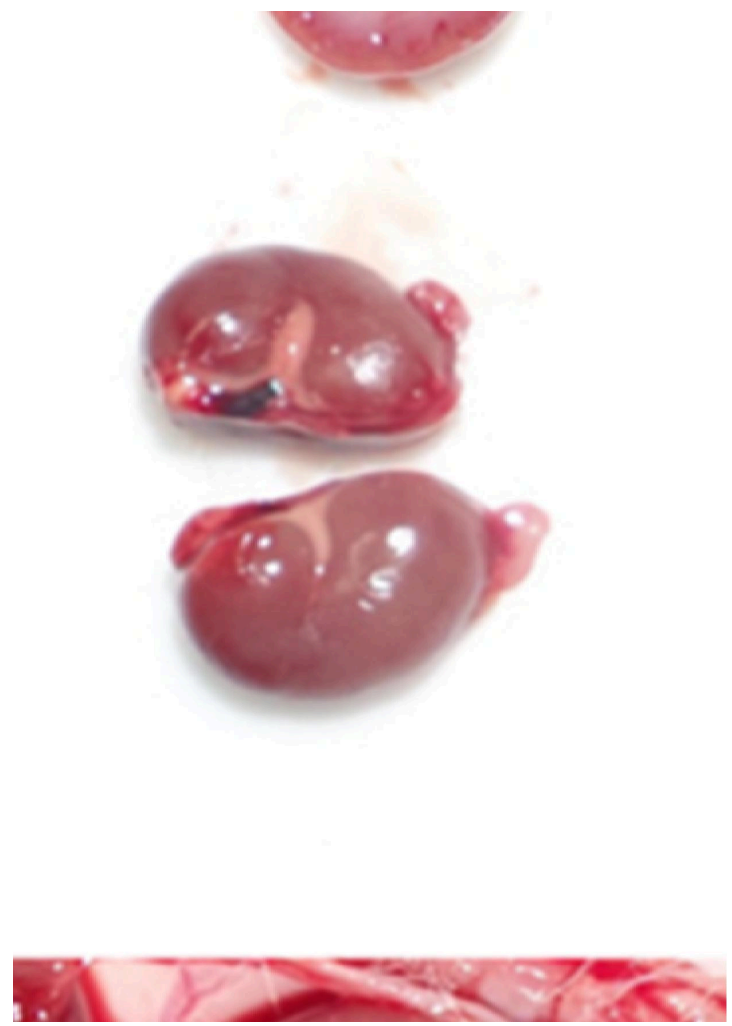

Figure 3. Kidneys CHV-1 FESC 2. Petechial and echymotic hemorrhages. 

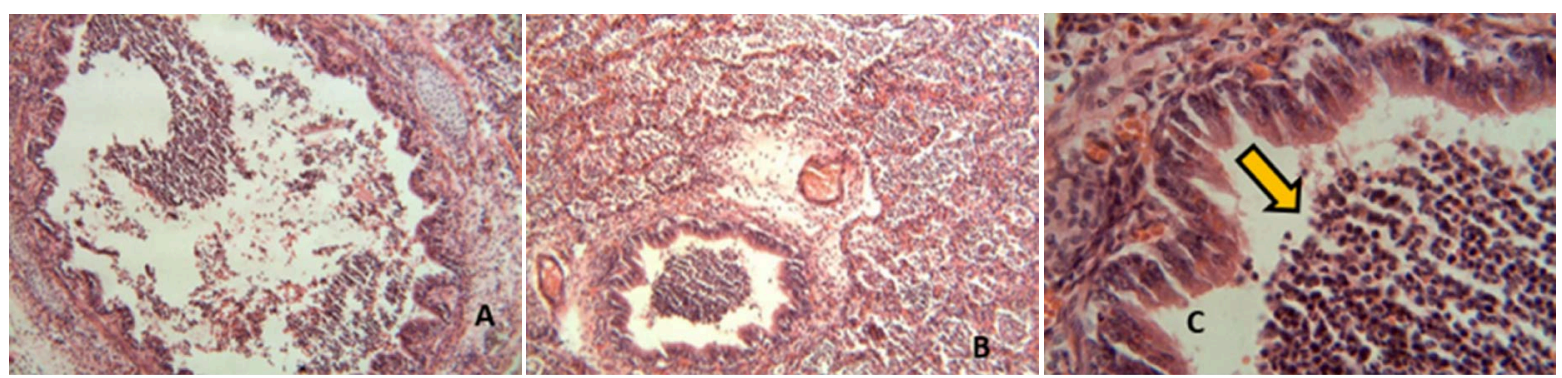

Figure 4. Lungs. A. Mild suppurative bronchitis CHV-1, FESC1, (40×). B. Mild suppurative bronchitis, diffuse proliferative interstitial pneumonia. CHV-1, FESC $2(100 \times)$. C. Suppurative bronchitis (arrow) CHV-1, FESC 2, (400×).

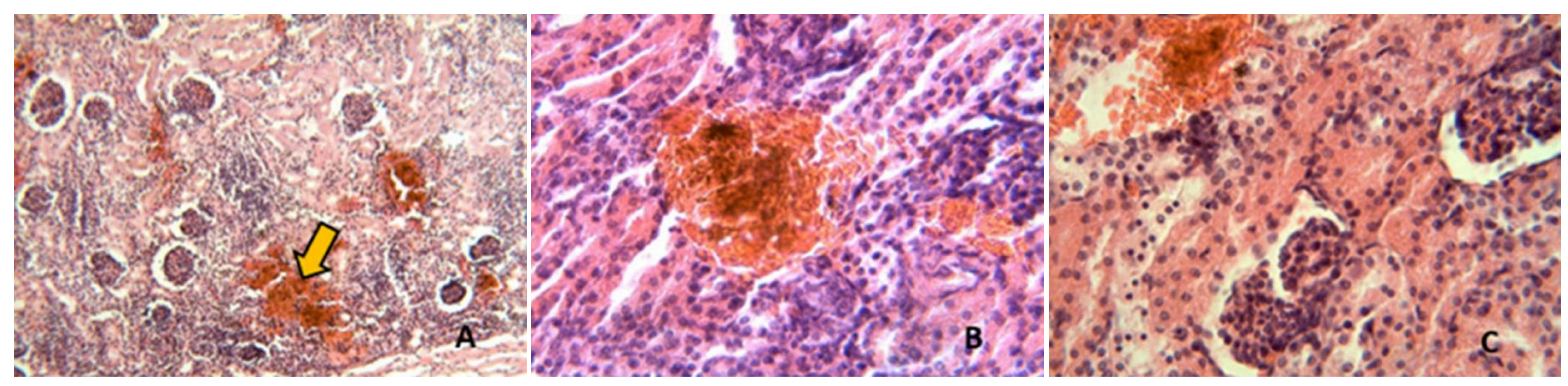

Figure 5. Kidneys. A. Severe proliferative intersticial nephritis, severe multifocal hemorrhages (arrow) CHV-1 FESC 2 $(400 \times)$. B. Mild hemorrhage, diffuse proliferative intersticial nephritis CHV-1 FESC 2, (400×). C. Hemorrhage spot, mild albuminous degeneration CHV-1 FESC 2 (400×).

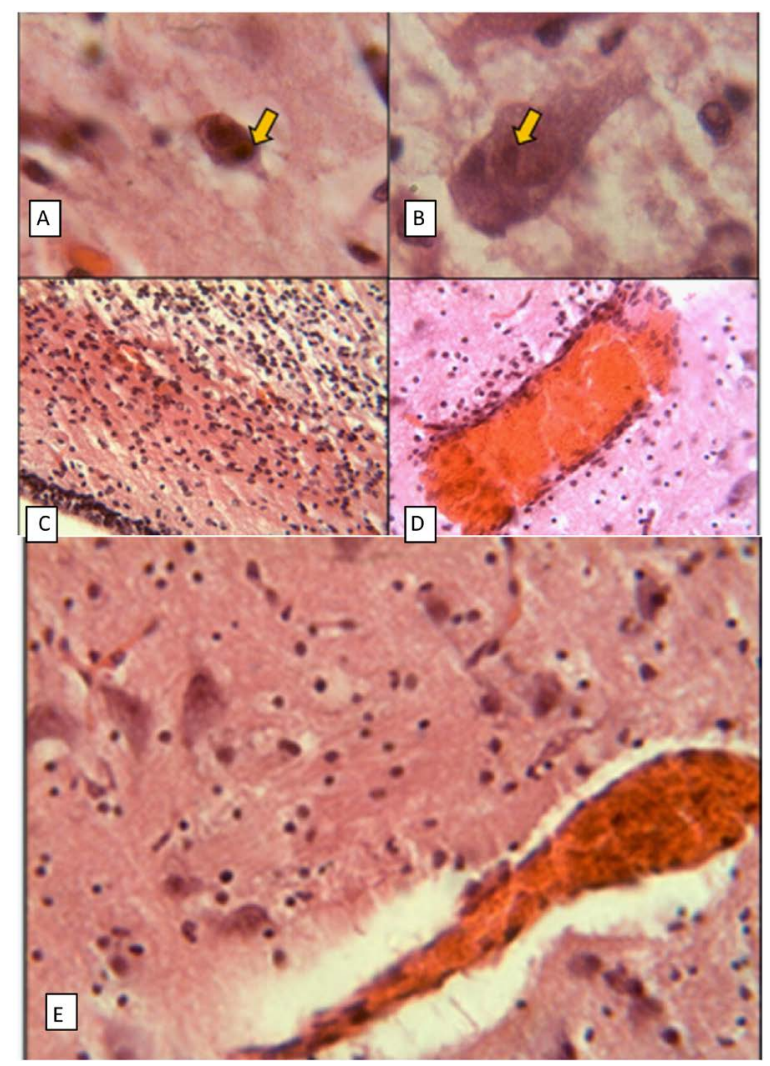

Figure 6. Brain. A. Intranuclear inclusion body, CHV-1 FESC 2 (1000×). B. Intranuclear inclusion body CHV-1 FESC 1 $(1000 \times)$. C. Non suppurative meningoencephalitis CHV-1 FESC $1(400 \times)$. D. Perivascular lymphocytic infiltration CHV-1 FESC $2(400 \times)$. E. Edema CHV1 FESC $1(400 \times)$. 
A strong positive IF reaction was observed, mainly in the nucleus, in all of the infected cell cultures (Figure 8). PCR amplification followed the protocol described by Van de Vanter in 1996 [10] and is shown in Figure 9.

Figure 10 shows the results for the PCR protocol described by Burr et al. in 1996 [11], which amplified a 120-bp fragment of glycoprotein B.

Particles associated with herpesvirus were identified with electron microscopy (Figure 11). The viral capsid was $100 \mathrm{~nm}$ in diameter, and the complete virion was between 200 and $280 \mathrm{~nm}$ in diameter.

\section{Discussion}

In newborn pups, the virus enters the bloodstream through leukocytes. Then, viral replication occurs in the vascular endothelium, leading to necrotizing vasculitis and hemorrhages [14] [15].

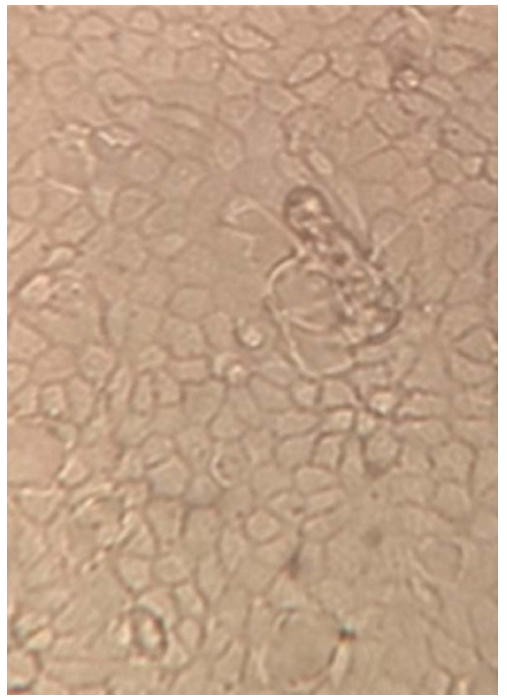

A

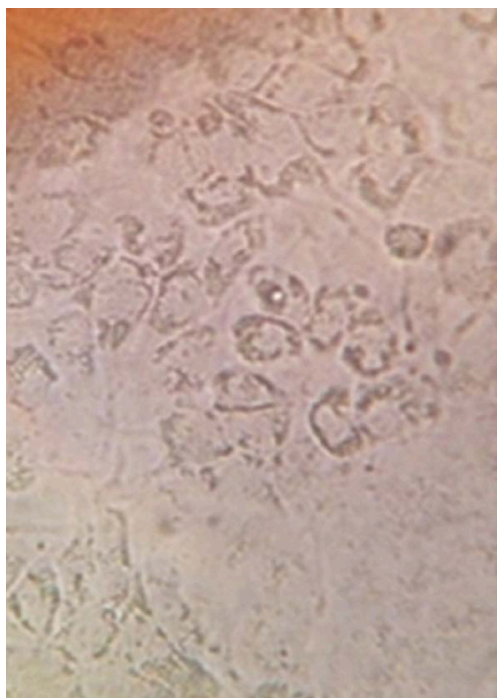

B

Figure 7. CHV-1 cytopathic effects on MDCK cells 48 hours post infection. A. MDCK control. B. CHV1 FESC 2 MDCK infection.
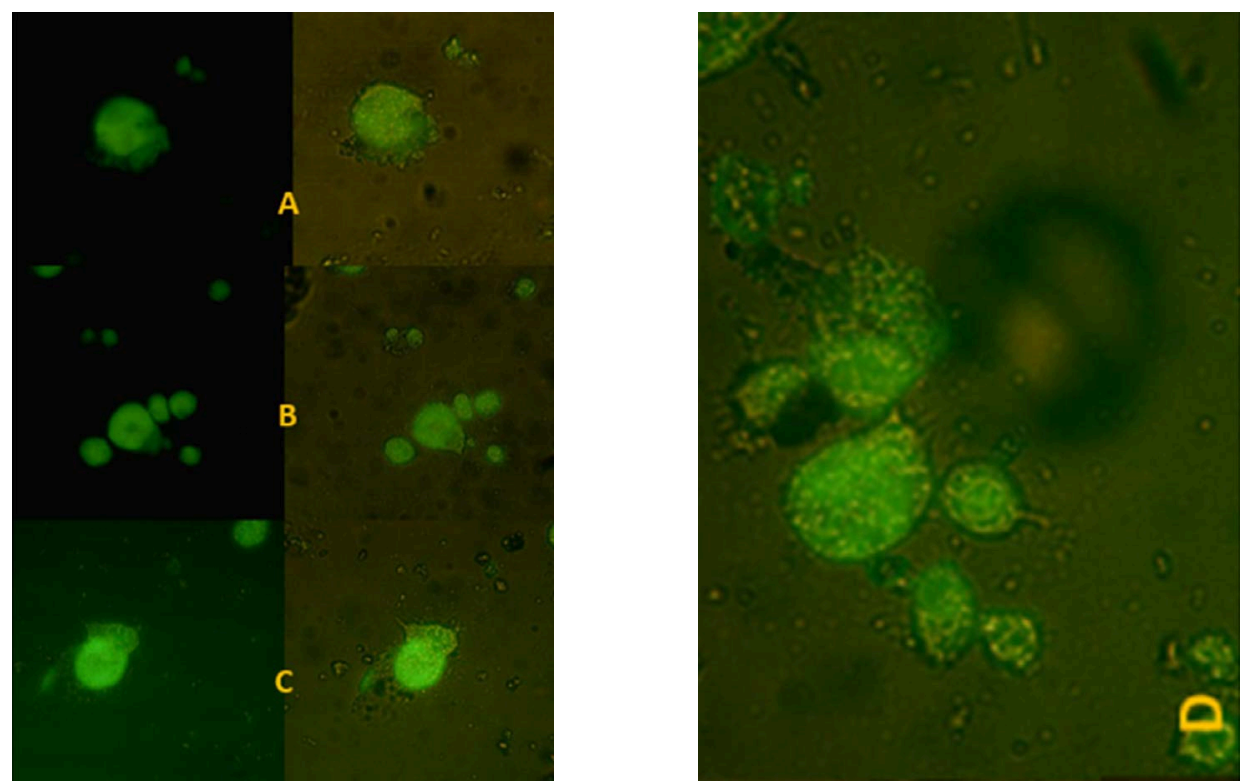

Figure 8. Immunofluorescence assay on cell culture. A. CHV-1 FESC 1. B. CHV-1 FESC 2. C. CHV-1 FESC 3. D. CHV-1 LCOBOS 1. 


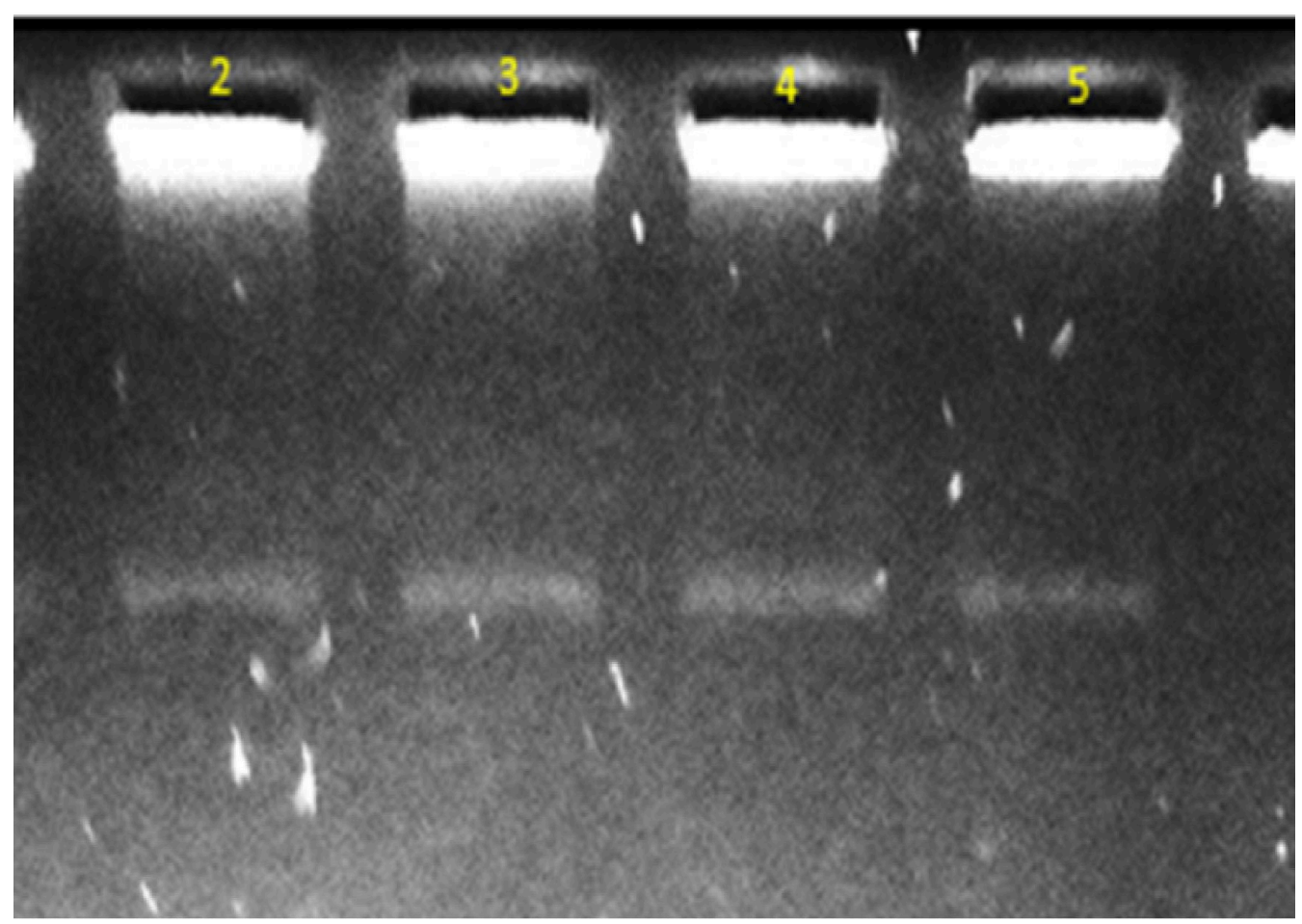

Figure 9. Agarose gel electrophoresis of Van de Vanter PCR protocol. Lane 1 (positive control), Lane 2 (CHV-1 FESC 1), Lane 3 (CHV-1, FESC 3). Lane 4 (CHV-1, FESC 3), Lane 5 (CHV-1 LCOBOS 1), Lane 6 (negative control). MWM = Molecular weight marker $(\mathrm{pb})$.

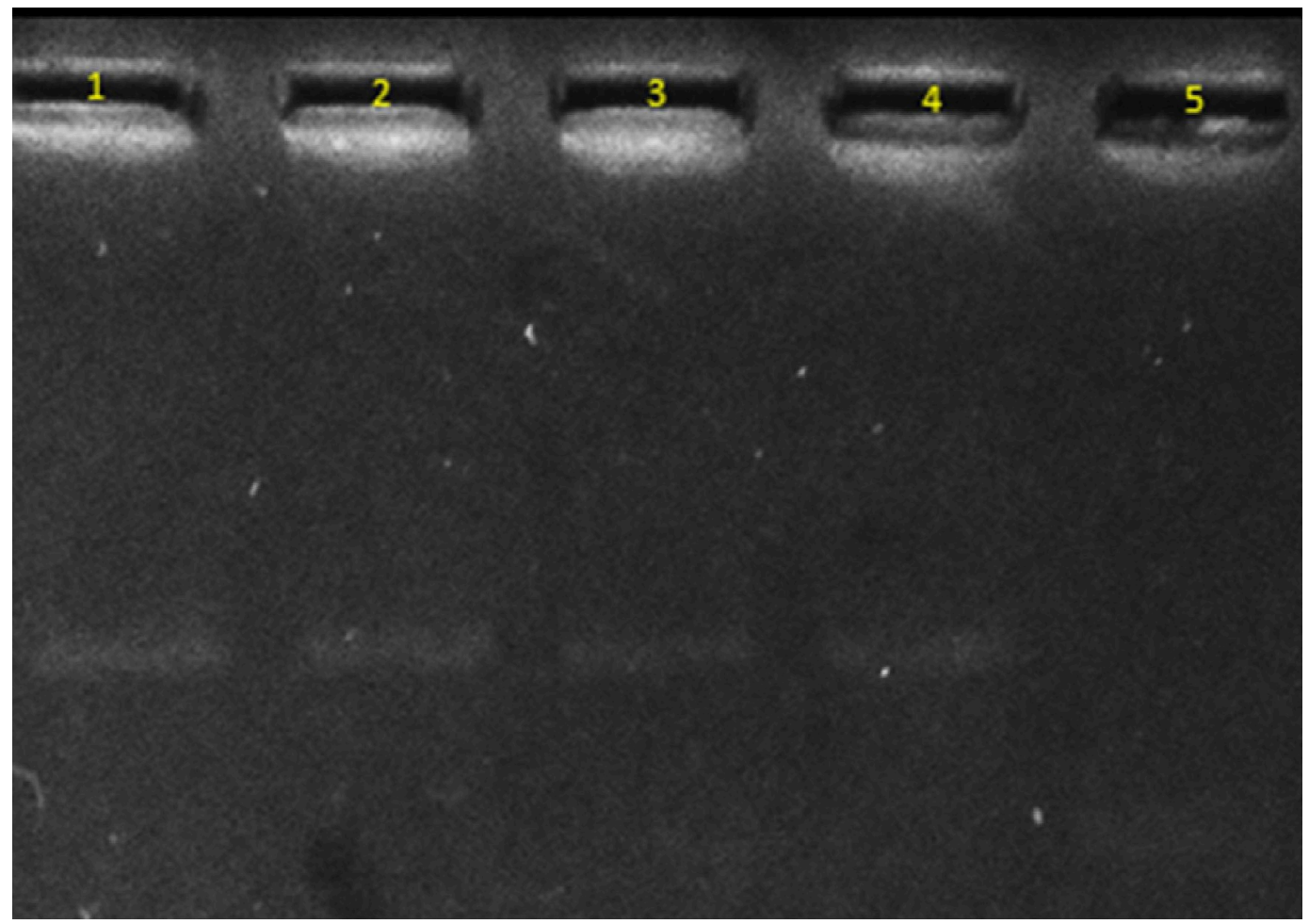

Figure 10. Agarose gel electrophoresis of Burr et al. PCR protocol. Lane 1 (CHV-1 FESC 1), Lane 2 (CHV-1 FESC 2), Lane 3 (CHV-1 FESC 3), Lane 4 (CHV-1 LCOBOS), Lane 5 (negative control). MWM = Molecular weight marker (pb). 
Table 1. Cythopathic effects on MDCK cells.

\begin{tabular}{ccc}
\hline CASE & ORGAN & EFFECTS \\
CHV-1FESC-1 & Brain & ++ \\
CHV-1FESC-1 & Liver & ++ \\
CHV-1FESC-1 & Kidney & ++ \\
CHV-1FESC-1 & Lung & ++ \\
CHV-1FESC-1 & Spleen & + \\
CHV-1FESC-2 & Brain & +++ \\
CHV-1FESC-2 & Liver & ++ \\
CHV-1FESC-2 & Kidney & ++ \\
CHV-1FESC-2 & Lung & ++ \\
CHV-1FESC-2 & Spleen & + \\
CHV-1FESC-3 & Brain & ++ \\
CHV-1FESC-3 & Liver & ++ \\
CHV-1FESC-3 & Kidney & ++ \\
CHV-1FESC-3 & Lung & ++ \\
CHV-1FESC-3 & Spleen & ++ \\
CHV-1L.COBOS-1 & C.E. & ++ \\
\hline
\end{tabular}

C.E. $=$ Chicken embryo, ${ }^{+}$Weak cytophatic effects, ${ }^{++}$Mild cytophatic effects, ${ }^{+++}$Moderate cytophatic effects, Strong cytophatic effects.
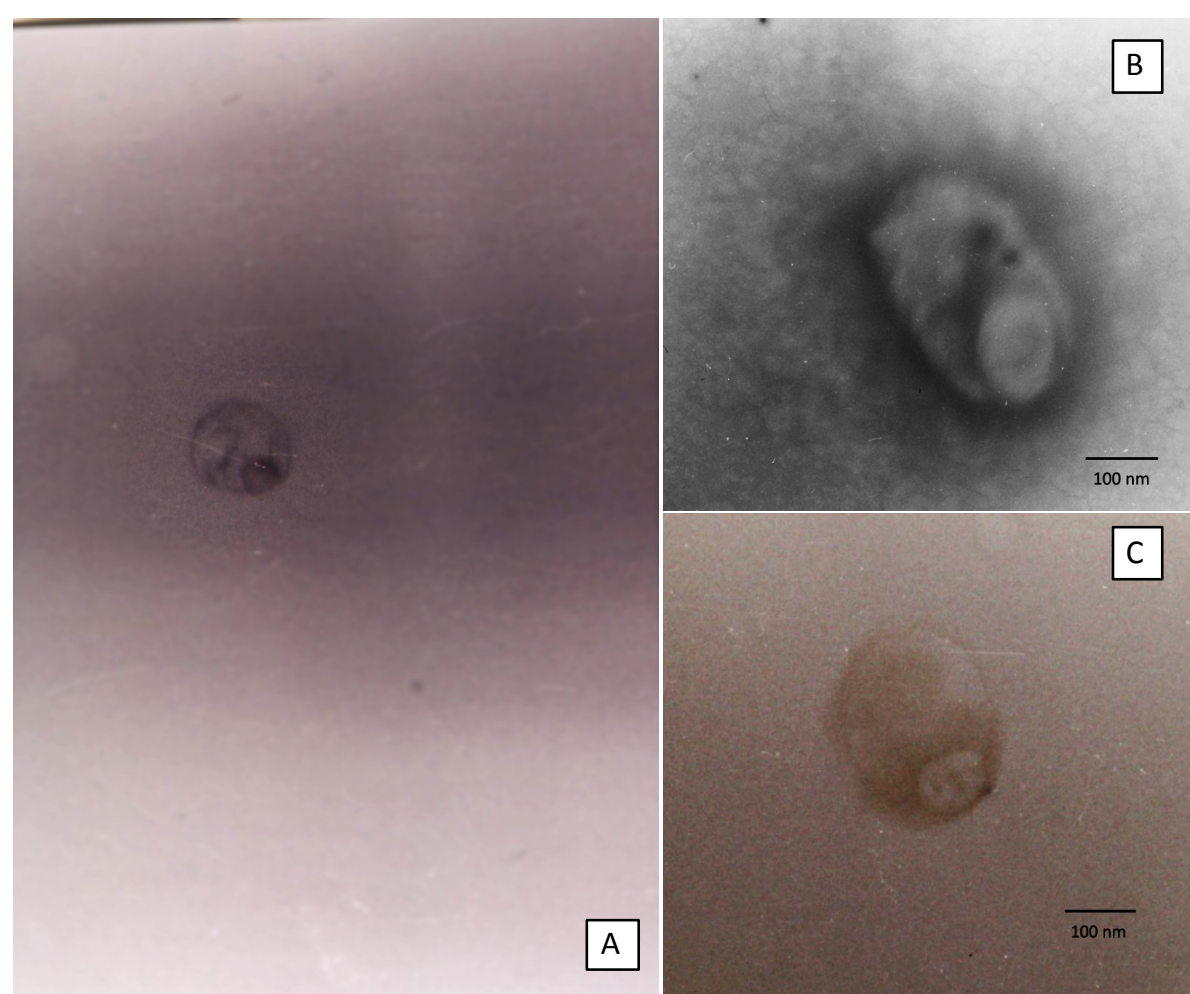

Figure 11. Transmission electron microscopy. Ac. Phosphotungstic stain. A. CHV-1 FESC 2 (15,000×). B. CHV-1 LCOBOS-1 (30,000×). C. CHV-1 FESC2 (30,000×). T = Tegument. NC = Nucleocapsid. EV = Viral envelope. 
Characteristic lesions of CHV-1 infections in newborn puppies include petechial to ecchymotic hemorrhages in multiple organs [12] [14] [15]. The three necropsies performed during this study showed hemorrhagic lesions in several organs, mainly the kidney, liver and lungs. Pathological findings were highly suggestive of canine herpesvirus; however, there are other etiologic agents that produce lesions in the vascular endothelium leading to secondary bleeding. Sepsis and endotoxemia are common causes of endothelial damage [16], while the canine adenovirus (CAV-1) replicates in vascular endothelial cells and hepatocytes, leading to ecchymotic and petechial hemorrhages in the organs of puppies [17]. Necrosis and hemorrhage were observed in the kidney and described as primary evidence during histopathology as features of CHV infection-1 [16], but to a lesser degree.

The histopathological findings from natural or experimental infections in newborns puppies were characterized by scattered foci of necrosis with peripheral hemorrhages in the kidneys, lungs, spleen, small intestine and brain [12]-[14]. These foci of necrosis and hemorrhages were found in the examined puppies, with hemorrhages being the most apparent, while necrosis was less prominent; however, no necrotic foci were found in the brain. Moreover, a strong leukocyte infiltration, with lymphocyte predominance, was found in the kidneys, brain and lungs. This was contrary to the results from Carmichael in 1965, who mentioned that low to mild leukocyte infiltrates can be found, although in general, are rare.

We were able to observe intranuclear inclusion bodies, consistent with the report by Greene in 2012 [18].

The immunofluorescence reaction was more pronounced in the vascular endothelium, mainly in the kidney and brain. This was consistent with McGavin and Zachary in 2007 [16], who indicated that viral replication occurs in vascular endothelium cells.

The amplified 250-bp product obtained through PCR was consistent with previous results because the amplified product was expected to be between 215 and 315 bp [10].

After inoculating the tissue samples, cytopathic and cytolytic effects were observed in canine cells (MDCK) in accordance with Strandberg and Aurelian, 1969 [8], who reported that the cytopathic effects were observed 48 hours post-infection, while cytolytic alterations were found after 72 hours. The viral isolates were identified by PCR, immunofluorescence and transmission electron microscopy. The PCR assays amplified DNA fragments within the expected ranges: approximately 250 bp for the DNA polymerase gene (Van de Vanter, 1996) and approximately 120 bp for the glycoprotein B gene [11]. Both results were consistent with those of the authors who developed the protocols.

The immunofluorescence technique, using a polyclonal conjugate against CHV-1, showed a fluorescent label in the nucleus and the cytoplasmic membrane, consistent with the evolution of the viral cycle and replication in the nucleus with the acquisition of proteins from tegument and nucleocapsid, while the envelope proteins are acquired through vesicles from the Golgi complex [19]. The virus leaves remnants of the envelope (including glycoproteins) on the cell membrane when entering another cell [20], which may explain the location of the fluorescent label. Notably, the manufacturer of the immunofluorescence reagent (VMRD ${ }^{\circledR}$ ) mentioned that there was a reaction with canine distemper virus (CDV) and virus type 2 parainfluenza (CPI-2); therefore, it should not be used as a single diagnostic method. Moreover, confirmation must be supported by another technique, such as PCR.

The results obtained by TEM for the structure and size of the virion matched those presented by Roizman and Knipe, 1992 [21]. This study also showed amorphous material around the capsid that was partially asymmetric [22].

\section{Conclusions and Implications}

We isolated CHV-1 viral strains and identified them with PCR, direct immunofluorescence and transmission electron microscopy. In addition, we established a relationship between the macroscopic and microscopic lesions from necropsied pups that died within the first 25 days and confirmed the presence of canine herpesvirus.

To date there is no evidence of the presence of canine herpesvirus in Mexico; the confirmation performed in this work implies that appropriate measures should be taken to prevent its spread and condition of animal health in Mexico; in addition they must implement appropriate diagnostic measures.

Further work should sequence the amplicons to establish the genetic lineage of these isolates and determine the phylogeny of the virus isolated in Mexico.

\section{Acknowledgements}

This work was supported by the Project PAPITT-UNAMIT-202114 “Assessment of canine herpesvirus disease 
development in Mexico and possible measures for control and prevention”.

\section{References}

[1] Lacheretz, A. and Cognard, S. (1998) Epidemiology and Serological Diagnosis of 10 Canine Herpesvirus. RevMédVét, 143, 1477-1488.

[2] Reading, M.J. and Field, H.J. (1998) A Serological Study of Canine Herpes Virus-1 Infection in the English Dog Population. Archives of Virology, 143, 1477-1488. http://dx.doi.org/10.1007/s007050050391

[3] Rijsewijk, F.A.M., Luiten, E.J., Daus, F.J., Van der Heijden, R.W. and Van Oirschot, J. (1999) Prevalence of Antibodies against Canine Herpesvirus 1 in Dogs in the Netherlands in 1997-1998. Veterinary Microbiology, 65, 1-7. http://dx.doi.org/10.1016/S0378-1135(98)00285-5

[4] Ronsse, V., Verstegen, J., Onclin, K., Guiot, A.L., Aeberle, C. and Nauwynck, H.J. (2002) Seroprevalence of Canine Herpesvirus-1 in the Belgian Dog Population in 1997-1998. Reproduction Domestic Animals, 37, 299-304. http://dx.doi.org/10.1046/j.1439-0531.2002.00363.x

[5] Carmichael, L.E. and Medic, B.L. (1978) Small-Plaque Variant of Canine Herpesvirus with Reduced Pathogenicity for Newborn Pups. Infection and Immunity, 20, 108-114.

[6] Ledbetter, E.C., Dubovi, E.J., Sung, G., Maggs, D. and Bicalho, R. (2009) Experimental Primary Ocular Canine Herpesvirus-1 Infection in Adult Dogs. American Journal of Veterinary Research, 70, 513-521. http://dx.doi.org/10.2460/ajvr.70.4.513

[7] Percy, D.H., Olander, H.J. and Carmichael, L.E. (1968) Encephalitis in the Newborn Pup Due to a Canine Herpesvirus. Veterinary Pathology, 5, 135-145.

[8] Strandberg, J.D. and Aurelian, L. (1969) Replication of Canine Herpesvirus. II. Virus Development and Release in Infected Dog Kidney Cells. Journal of Virology, 4, 480-489.

[9] Takumi, A., Kusanagi, K., Tuchiya, K., Xuan, X. and Azetaka, M. (1989) Serodiagnosis of Canine Herpesvirus Infection-Development of an Enzime-Linked Immunosorbent Assay and Its Comparison with Two Improved Methods of Serum Neutralization Test. Japan Journal Veterinary Science, 52, 241-250. http://dx.doi.org/10.1292/jvms1939.52.241

[10] VanDevanter, D.R., Warrener, P., Bennett, L., Schultz, E.R., Coulter, S., Garber, R.L. and Rose, T.M. (1996) Detection and Analysis of Diverse Herpes Viral Species by Consensus Primer PCR. Journal of Clinical Microbiology, 34, 1666-1671.

[11] Burr, P.D., Campbell, M.E.M., Nicolson, L. and Onions, D.E. (1996) Detection of Canine Herpesvirus 1 in a Wide Range of Tissues Using the Polymerase Chain Reaction. Veterinary Microbiology, 53, 227-237. http://dx.doi.org/10.1016/S0378-1135(96)01227-8

[12] Carmichael, L.E., Squire, R.A. and Krook, L. (1965) Clinical and Pathologic Features of a Fatal Viral Disease of Newborn Pups. American Journal of Veterinary Research, 26, 803-814.

[13] Love, D.N. and Huxtable, C.R. (1976) Naturally-Occurring Neonatal Canine Herpesvirus Infection. The Veterinary Record, 99, 501-503. http://dx.doi.org/10.1136/vr.99.25-26.501

[14] Poulet, H., Guigal, P.M., Soulier, M., Leroy, V., Fayert, G., Minke, J. and Chappuis, M. (2001) Protection of Puppies against Canine Herpesvirus by Vaccination of the Dams. The Veterinary Record, 148, 691-695. http://dx.doi.org/10.1136/vr.148.22.691

[15] Wright, N.G. and Cornwell, H.J. (1968) Experimental Herpes virus Infection in Young Puppies. Research in Veterinary Science, 9, 295-299.

[16] McGavin, M.D. and Zachary, J.D. (2007) Pathological Basis of Veterinary Disease. 4th Edition, Mosby-Elsevier, St Louis Missouri.

[17] Decaro, N., Amorisco, F., Desario, C., Lorusso, E., Camero, M., Bellacicco, A.L., Sciarretta, R., Lucente, M.S., Martella, V. and Buonavoglia, C. (2010) Development and Validation of a Real-Time PCR Assay for Specific and Sensitive Detection of Canid Herpesvirus 1. Journal of Virological Methods, 169, 176-180.

http://dx.doi.org/10.1016/j.jviromet.2010.07.021

[18] Greene, C.E. (2012) Canine Herpevirus Infection. 4th Edition, Saunders, New York.

[19] Maurer, U.E., Zeev-Ben-Mordehai, T., Pandurangan, A., Cairns, T., Hannah, B., Whitbeck, J.C., Eisenberg, R.J., Cohen, G.H., Topf, M. and Huiskonen, J.T. (2009) The Structure of Herpesvirus Fusion Glycoprotein B-Bilayer Complex Reveals the Protein-Membrane and Lateral Protein-Protein Interaction. Cell Structure, 21, 1396-1405. http://dx.doi.org/10.1016/j.str.2013.05.018

[20] Spear, P.G. (2004) Herpes Simplex Virus: Receptors and Ligands for Cell Entry. Cellular Microbiology, 6, $401-410$. http://dx.doi.org/10.1111/j.1462-5822.2004.00389.x 
[21] Roizmann, B., Desrosiers, R.C., Fleckenstein, B., Lopez, C., Minson, A.C. and Studdert, M.J. (1992) The Family Herpesviridae: An Update. The Herpesvirus Study Group of the International Committee on Taxonomy of Viruses. Archives of Virology, 123, 425-449. http://dx.doi.org/10.1007/BF01317276

[22] Wagner, M., Ruzsics, Z. and Koszinowski, U.H. (2002) Herpesvirus Genetics Has Come of Age. Trends in Microbiology, 10, 318-324. http://dx.doi.org/10.1016/S0966-842X(02)02394-6

\section{Submit or recommend next manuscript to SCIRP and we will provide best service for you:}

Accepting pre-submission inquiries through Email, Facebook, Linkedin, Twitter, etc A wide selection of journals (inclusive of 9 subjects, more than 200 journals)

Providing a 24-hour high-quality service

User-friendly online submission system

Fair and swift peer-review system

Efficient typesetting and proofreading procedure

Display of the result of downloads and visits, as well as the number of cited articles

Maximum dissemination of your research work

Submit your manuscript at: http://papersubmission.scirp.org/ 